\title{
Island Ramanacoil a Bridge too Far. A Dutch Ciphertext from 1674
}

\author{
Jörgen Dinnissen \\ Historian and \\ consultant business analytics, \\ The Netherlands \\ dinnissen.jorgen@gmail.com
}

\author{
Nils Kopal \\ University of Siegen, \\ Germany \\ nils.kopal@uni-siegen.de
}

\begin{abstract}
The deciphered Ramanacoil ciphertext reveals two Dutch East India Company letters, from 1674 that are, in retrospect, already known in the National Archives as plaintext letters. The letters are written in Dutch. We have been able to relate them. The first letter, from Van Goens senior from Sri Lanka to the Lords Seventeen in The Netherlands, was most important to the sender. He sent his personal secretary Leeuwenson overland with the ciphertext in his pocket and its key in his head. And with additional oral information that had to be delivered in person. Van Goens senior requested to conquer the whole of Sri Lanka, the island Ramanacoil and coastal area around it along with 1,000 more soldiers. This paper shows that by sending Leeuwenson, Van Goens senior wanted to repeat his most successful 'Vertoog' from 1655. Substantiate his strategic goals and get approval for them from the Lords Seventeen. In 1655 he got a 'Go!' and twenty years later in 1675 he got a 'No!'. The zeitgeist of expansion had changed. Ramanacoil was a bridge too far.
\end{abstract}

\section{Introduction}

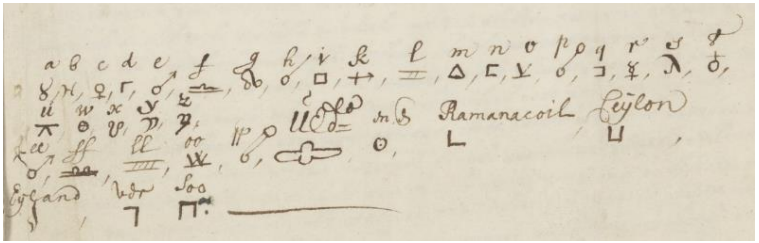

Figure 1: Key from the Ramanacoil ciphertext.

The Ramanacoil ciphertext is a 46 pages manuscript - with 39 pages of ciphertext and one page with the key - of the Dutch East India Company (VOC) located at the National
Archives, The Hague, The Netherlands (Ramanacoil, 1674). The description of this manuscript reads: "piece in unknown language without Dutch heading; encrypted text with key probably related to Ramanacoil." This is based on the words Ramanacoil and Ceylon in the key (see Figure 1).

From an initial inventory the ciphertext did not appear to be deciphered. In retrospect it turned out that it was deciphered by Van Meersbergen (2009). This only became clear after conducting follow-up research with the name of the man, Joannes Leeuwenson, who encrypted (Dutch: in caracters gebragt) the plaintext in 1674. Van Meersbergen didn't make a transcription. He deciphered the ciphertext of all pages directly into plaintext with the straightforward key in his head. (Notice: Plaintext can also be a transcription. But for us here, we define that transcription is a digitized text that can be used for further (crypt-)analysis.) Only the first revealed plaintext page of the ciphertext is published in Van Meersbergen (2009).

\begin{tabular}{|l|l|}
\hline Ciphertext & I \\
\hline Manual transcription & $\begin{array}{l}\text { Earth ' Quincunx Taurus Gamma } \\
\text { Male Mercury Gemini Taurus } \\
\text { SquareRight Earth }\end{array}$ \\
\hline $\begin{array}{l}\text { Revealed plaintext as } \\
\text { CT2 output }\end{array}$ & T'UADERLANT \\
\hline $\begin{array}{l}\text { Translation from } \\
\text { Dutch into English }\end{array}$ & The Fatherland \\
\hline
\end{tabular}

Table 1: First word of the ciphertext deciphered. 
Crina Tudor and her team of five students from Uppsala University, Sweden made a digital transcription of all pages manually. They assigned each ciphertext symbol to a transcription word. This transcription was used as input in the software CrypTool 2 (CT2). Using the digitized nomenclature CT2 generated the plaintext used for this paper. The Table 1 shows the very first word of the document in ciphertext, transcription, revealed plaintext in Dutch, and its translation into English.

Next to the ciphertext we found six manuscripts in the National Archives that are relevant for interpretating it. One of them is a daily register (Dutch: Daghregister) that the encrypter Leeuwenson (1675) made during his overland journey from Ceylon (present day Sri Lanka) to Amsterdam.

This paper is structured as follows: Section 2 gives a summary of the two letters that are hidden in the ciphertext and provides background information. Section 3 takes a closer look at the register of Leeuwenson and two other letters in which he is mentioned. Section 4 shows two identical plaintext copies of these letters found in the National Archives. Section 5 discusses the importance of the ciphertext and whether the requests were granted. The technical matters of the used cipher are discussed in Section 6, and we give recommendations regarding transcriptions done manually. Finally, in Section 7 , we draw three conclusions.

\section{Content of the two letters}

The ciphertext consists of two letters that bring us at a decisive period of the VOC in which, in retrospect, its expansion reached its limits. What strategic-military choices do we have to make and which ones are crucial for trading? Van Goens senior was one of the protagonists in these discussions. ${ }^{1}$

\footnotetext{
${ }^{1}$ The background information of Subsections 2.1 and 2.2 are based on: Gaastra (2012), Knaap and Teitler (2002), Knaap et al. (2015), and Van Meersbergen (2009 and 2011).
}

\section{$2.1 \quad$ VOC}

The business concept of the VOC (1602-1800) was: cashing in price differences for products from the East Indies (read: Asia and not the south of present day country India) in Europe. They wanted to achieve this with a 'Grand Strategy' of three main goals:

1. Establishing a monopoly on spices on the Moluccas (present day Maluku Islands, Indonesia). This goal was achieved in 1666.

2. Taking control of the pepper and textile trade in the south of India and establishing a monopoly on cinnamon on Ceylon. This goal was achieved in 1663 .

3. Taking control of the silk trade in China. This goal was never achieved. After the surrender of Fort Zeelandia on Formosa (present day Taiwan) in 1662 the company had to admit that this goal had failed.

The VOC's power was exercised through fortifications, spread throughout Asia, on the landward side of the sea. At sea, armed merchant ships usually sailed back to the Netherlands in convoy with warships for protection. In times of tension, expansion, or punitive expeditions, additional ships were deployed in fleets with a lot of firepower and soldiers. The company was above all a maritime power with a strong fleet. They were mainly interested in trade and not in territorial expansion.

Around 1674 the VOC had 200 to 250 fortifications. The headquarters of Asia were in Batavia (present day Jakarta, Indonesia). Formally, the governor of the Ceylon government was subordinate to the governor general in Batavia. With the appointment of Van Goens senior in 1655, Batavia faced serious competition from Ceylon as a second return port.

A few numbers: in 1687, the company in Asia employed 12,000 European employees of whom 8,000 were soldiers; 3,000 employees were employed both in Batavia and Ceylon of which 2,000 were soldiers. In addition to the staff from Europe, there were 8,000 local employees and slaves at work. Of which 2,000 were working at Batavia and 3,000 at Ceylon. 


\subsection{Superintendent and former governor of Ceylon Van Goens senior}

Until 1670 Rijckloff van Goens senior (16191682) was a successful diplomat and warrior whose great Ceylon project seemed to be realizable. He had been a successful diplomat in present day Indonesia and belonged, at the age of 37 , to the top in Batavia before he travelled to The Netherlands.

In 1655 he was allowed to unfold his plans (Dutch: Vertoog) for Asia to the Lords Seventeen (board of the VOC) in Amsterdam. After this he got a 'Go!' to personally lead the conquests of northwest India (Diu), island Ceylon, and south India (Tutucorin). They were realized in 1658 with the exception of Diu. In 1663 he also conquered Cochin on the southwest coast of India (Malabar), the heartland of the pepper trade.

Van Goens senior was governor for the Ceylon government from 1662-1663 and 16651671. In 1671 he was succeeded by his son Rijckloff van Goens junior (1642-1686). Senior became superintendent (Dutch: opperkoopman) but it was clear to everyone that senior was still in charge.

\subsection{Island Ramanacoil and Ceylon}

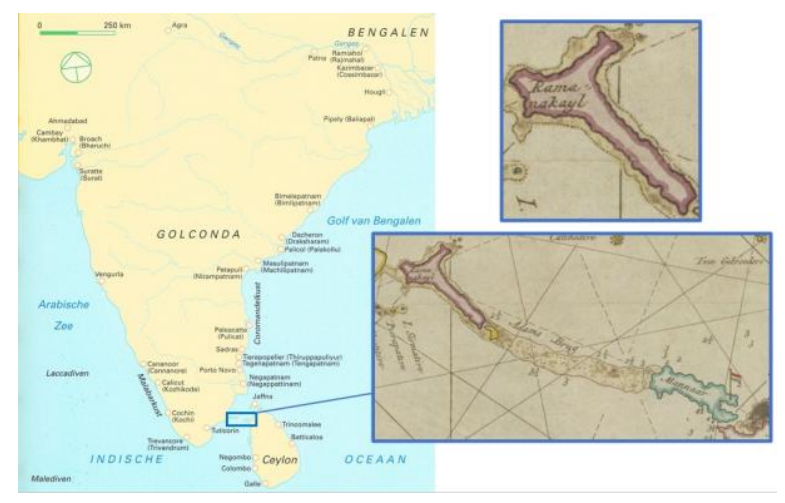

Figure 2: India and Ceylon. Ramanacoil, Adam's Bridge, and Manaar enlarged. The 'Map India' is cropped and published with permission from Bert Stamkot and taken from Gaastra (2012: 53).

Ramanacoil (present day Rameswaram) is an island against the mainland of south India (see Figure 2). Across Adam's Bridge (Dutch: Adams brug) on the other side is the island of Manaar, which in turn lies against the island of Ceylon. In 1674 the coast of Ceylon was in the possession of the VOC and the interior was in the hands of the King of Kandy.

\subsection{The two letters of the ciphertext}

The ciphertext contains two letters written in Dutch. Letter One from Van Goens senior to the Lords Seventeen in The Netherlands consists of six pages ciphertext. Letter Two, which has 33 pages, is addressed to the governor general in Indonesia. See Table 2, for more details about the two letters: sender, encrypter, and receiver.

\begin{tabular}{|l|l|l|}
\hline & Letter one & Letter two \\
\hline Number of pages & 6 & 33 \\
\hline $\begin{array}{l}\text { Key (same key for both } \\
\text { letters) }\end{array}$ & available & available \\
\hline Date & $1674-01-24$ & $1674-01-23$ \\
\hline Plaintext language & Dutch & Dutch \\
\hline Sender name & $\begin{array}{l}\text { Van Goens senior, Van } \\
\text { Goens junior and board } \\
\text { of Ceylon government }\end{array}$ & $\begin{array}{l}\text { Van Goens senior, Van } \\
\text { Goens junior and board } \\
\text { of Ceylon government }\end{array}$ \\
\hline Sender place & VOC, Ceylon & VOC, Ceylon \\
\hline Receiver name & VOC, Lords Seventeen & $\begin{array}{l}\text { VOC, governor general } \\
\text { and board of Asia }\end{array}$ \\
\hline Receiver place & $\begin{array}{l}\text { Amsterdam, } \\
\text { The Netherlands }\end{array}$ & $\begin{array}{l}\text { Batavia, } \\
\text { Indonesia }\end{array}$ \\
\hline Encrypter & Leeuwenson & Leeuwenson \\
\hline Content & $\begin{array}{l}\text { Strategical information } \\
\text { about the future of VOC } \\
\text { in Asia. Request for } \\
\text { expansion and 1,000 } \\
\text { more soldiers }\end{array}$ & $\begin{array}{l}\text { Operational information } \\
\text { of the ins and outs of the } \\
\text { Ceylon government }\end{array}$ \\
\hline \multicolumn{2}{|l}{} \\
\hline
\end{tabular}

Table 2: The two letters of the ciphertext.

\subsection{Letter One: from Van Goens senior on Ceylon to the Lords Seventeen in Amsterdam}

Summary of the content: The company has expelled the French from city Trincomali, Ceylon (Dutch: principale haven deses eylants). We must avoid that a European competitor takes possession of a part of Ceylon. The King of Kandy cooperates with the English, Portuguese, and French. He cannot be trusted. Only after learning this, we took actions to occupy all of Ceylon and not only a part. We must take possession of all of Ceylon! Ceylon is a better place than Batavia to protect Asia. It is in the heart of Asia. Without Ceylon, Asia is in danger (Dutch: los). On Ceylon is everything we want.

We have to take possession of the island Ramanacoil and the region below Adams Bridge (Madura) and above (land of Tanjore). With 200300 men, Ramanacoil can be defended against 
European and local competitors. Without Ramanacoil, everything on Ceylon is in danger. Dutch: eylandt Rammenecoyl, sonder t'welck alles op Ceylon los is.

Make whole Malabar including Cananur and a part of Coromondel (from Nagapatnam to Cranganoor) subordinate to Ceylon. Unity is strength. Then Ceylon gets stronger, we will overcome the costs (Dutch: lasten) in a few years and earnings will double.

Last sentence before signing: Send at least 1,000 soldiers directly to us. We are so weak that a few soldiers will not help. Ceylon's large fleet has consumed so much that all supplies have been devoured.

See Figure 3 for the wish list of expansions of Van Goens senior in 1674.

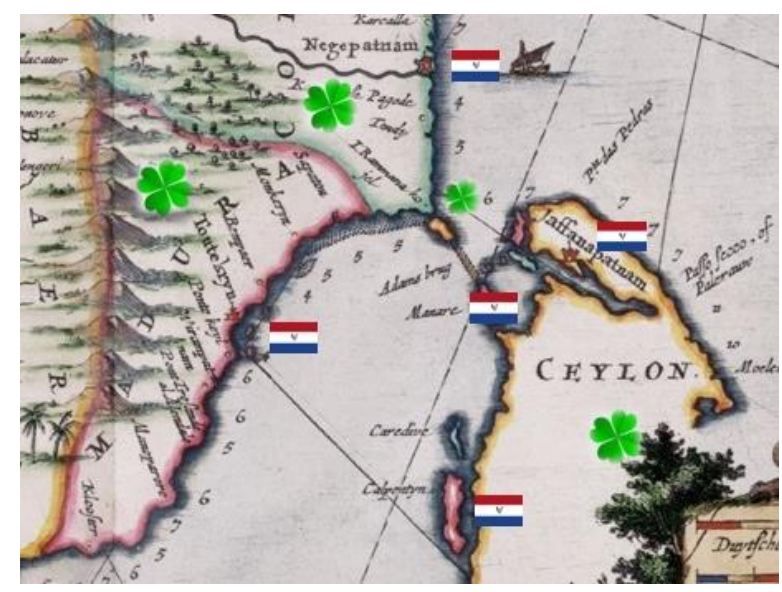

Figure 3: The wish list of expansions ('clover') of Van Goens senior in 1674 on a Dutch map from 1682. The Dutch fortifications have a 'VOC flag'.

\subsection{Letter Two: from Van Goens senior on Ceylon to governor general in Batavia}

Summary of the content: Trade in products: what comes from where in what quantities. Information about employees: appointments, deceased, requests for salary increases, employees to be penalized. Ships repaired.

Due to looting, seven of the ten English ships at Masulipatnam on the Coromandel coast have not been captured. Otherwise, the entire English fleet would have fallen into our hands and we could have conquered St. Thomé in 5-6 days. We hope for peace with England. We are going to conquer St. Thomé together with the Moors. Please, send an additional armed force around 1674-04-01. What should we do with St. Thomé once it is conquered? Trade it for the smelly Palleacatte? We await further orders.

Permission to take Ramanacoil and the coast of Madura in possession. They are important to keep Ceylon into our possession.

We have "absolutely" overcome the attacks from the men of the King of Kandy, Raja Sinha. They burned our brown rice (Dutch: nely) and knocked off the heads of four soldiers. Raja Sinha is a horrible tyrant. He slept with the only princess in the country: his father's sister. A daughter was born from that relationship.

Request for more capacity of European employees. Soldiers from Ambon do a good job, we wish we had 2,000-3,000 more of them to build a militia. Request of 100 horses more to do patrols with.

The Portuguese language in schools and churches has been abolished. Only our national language is used.

\section{Encrypter Leeuwenson and his overland journey}

In 1674 secretary Leeuwenson was ordered by his boss Van Goens senior to travel overland from Ceylon to Amsterdam with a soldier as company. The overland route can theoretically be covered in less than four months. Over sea with a sailing ship would take him seven months from Ceylon to Amsterdam. But the Dutch and the VOC were at war with France, England, and a few other countries during the Franco-Dutch War (1672-1678) and Van Goens senior wanted to be sure (Dutch: apparentie om de seckerheijt) that his most important letter was delivered swiftly in Amsterdam. In June 1673 most ships with letter books sent to The Netherlands were confiscated by the English near Saint Helena and Van Goens senior did not trust the route over the seas. 


\subsection{Overland journey from Ceylon to Amsterdam}

During his journey Leeuwenson (1675) kept a register. $^{2}$ In this, we read that he encrypted two copy letters handed over to him by Van Goens senior and that he sent them back to his boss with the key. Van Goens senior ordered Leeuwenson to encrypt these two most important letters to ensure that the scope of these letters would be hidden to their enemies in case they would be intercepted. In Dutch: dat ick de twee voorgemelde importante brieven in caracters zoude stellen, opdat (indien deselve onderschept wierden) de teneur voor onse vianden verborgen.

In the register we read that Leeuwenson had to consult VOC employees De Hase in Gamron and Repelaer in Basra how and where to cross overland exactly from Basra (present day Iraq) to Aleppo (present day Syria). This stretch was the only part of the journey the company couldn't provide protection for. A part of the journey where no difficulties were expected (Dutch: reijse waar geen swaerigheijt in gelegen is). In Basra they changed their Dutch into modest "Turkish" cloths and their hair was cut. To avoid suspicion, they had to pretend to be ordinary and poor traders and not employees of the VOC. With letters of introduction, guides, interpreters, paying tolls, and paying a "reasonable gift" (Dutch: redelijcke schenkagie) to three Sheikhs who were the heads of four groups of raiders, Leeuwenson and soldier Van Daelen were able to cross the desert. A crossing that was not without danger, but that was justifiable with the right precautions and the willingness of paying money. The fact that Leeuwenson kept a diary, in his luggage, for the VOC, in cleartext, in which he writes that he encrypted the letters and for whom, indicates that they did not expect to be intercepted. The encryption was a precaution.

Van Meersbergen (2011) writes that for VOC employees the landroute from Basra to Aleppo was forbidden since 1624. The Dutch and all

\footnotetext{
${ }^{2}$ Leupe (1863) transcribed and published the handwritten journal Leeuwenson (1675) kept of his overland journey.
}

other countries in Asia used Armenian traders and French clergymen for postal delivery, back and forth, between Aleppo and Basra. During the war with France in 1674 they were not trusted with these most important letters. Leeuwenson had to deliver them in person.

On 1675-1-5 Leeuwenson arrived in Amsterdam and he delivered the letters the same day to the Lords Seventeen. The letters were handed over to him almost one year before. In his register Leeuwenson never mentions when he decrypted his ciphertext. He must have done this somewhere between Aleppo and Amsterdam. Or was it done after his delivery in Amsterdam? Was his additional oral information sufficient? We cannot say this with certainty because we don't have the revealed plaintext from 1675 . Next to that, no interview report is known of the content of Leeuwenson's meeting with the Lords Seventeen.

\subsection{Letters with additional information}

What additional information can we gather from other sources about the ciphertext and the key? In Van Goens' (1674d) letter from 1674-2-10 to the Lords Seventeen we read that Leeuwenson will orally provide (Dutch: bij monde) additional information to the Lords Seventeen about "many matters that should not be entrusted to paper". Van Goens senior adds that Leeuwenson speaks Latin, French, and Portuguese well.

In the letter from 1674-5-2, De Hase (1674) writes that Leeuwenson told him that the "important letters" were encrypted and couldn't be helpful to anyone (Dutch: niemand sich soude connen dienen) even if they had them in their hands. Without his presence, the Lords Seventeen can't do anything with these letters (Dutch: sonder sijne presentie niet gedient conden sijn).

From the above we draw the conclusion that Leeuwenson was sent from Gamron - where De Hase wrote his letter - to The Netherlands with the ciphertext in his pocket and the key in his head. Without him neither the Lords Seventeen, nor the enemy, nor anyone else would be able to 
read these most important letters. Next to the letters, he had additional information in his head that could not even be entrusted to paper. It had to be told in person, face to face, to the Lords Seventeen.

\section{Plaintext copies of the two letters in the National Archives}

In the National Archives there is a plaintext copy of the 1674-1-24 letter sent from Van Goens senior to the Lords Seventeen in Amsterdam (Van Goens, 1674a) and of the 1674-1-23 letter sent to the governor general in Batavia (Van Goens, 1674b). ${ }^{3}$ In Table 3 and Table 4 they are compared. Leeuwenson (1675) tells that the ciphertext was based on two copy letters. The plaintext letter from 1674-1-24 is neither the revealed plaintext from the ciphertext nor the original or copy letter it was based on. For the 1674-1-23 letter, we must draw the same conclusion as for the 1674-1-24 letter.

\begin{tabular}{|l|l|}
\hline Revealed plaintext cipher & $\begin{array}{l}\text { Plaintext letter Van Goens, } \\
\text { 1674a }\end{array}$ \\
\hline $\begin{array}{l}\text { Signed 1674-1-24 } \\
\text { list with signatories; } \\
\text { one name not filled in } \\
\text { (“...") }\end{array}$ & $\begin{array}{l}\text { Signed 1674-1-24 } \\
\text { list with signatories; } \\
\text { not filled in name is replaced by } \\
\text { Cornelis Strick; } \\
\text { name Wiltvanck is missing }\end{array}$ \\
\hline $\begin{array}{l}\text { In minuut 1674-2-9 by } \\
\text { Leeuwenson secretary }\end{array}$ & $\begin{array}{l}\text { In minuut 1674-7-7 by Schoock } \\
\text { clerk }\end{array}$ \\
\hline $\begin{array}{l}\text { Encoded 1674-3-7 by } \\
\text { Leeuwenson }\end{array}$ & \\
\hline
\end{tabular}

Table 3: Two plaintexts of letter 1674-1-24 to the Lords Seventeen in Amsterdam compared.

\begin{tabular}{|l|l|}
\hline Revealed plaintext cipher & $\begin{array}{l}\text { Plaintext letter Van Goens, } \\
\mathbf{1 6 7 4 b}\end{array}$ \\
\hline $\begin{array}{l}\text { Signed 1674-1-23 } \\
\text { list with signatories }\end{array}$ & $\begin{array}{l}\text { Signed 1674-1-23 } \\
\text { list with signatories }\end{array}$ \\
\hline Accorded by Schoock clerk & One of eight copy letters \\
\hline $\begin{array}{l}\text { Encoded 1674-2-28 by } \\
\text { Leeuwenson secretary }\end{array}$ & \\
\hline
\end{tabular}

Table 4: Two plaintexts of letter 1674-1-23 to the governor general in Batavia compared.

\footnotetext{
${ }^{3}$ We also found an 'Appendix' dated 1674-1-24 from Van Goens senior to the Lords Seventeen in plaintext (Van Goens, 1674c). This 'Appendix' was not included in the ciphertext. We have analyzed its content but it gives no additional information about the ciphertext or key. List with signatories: Van Goens junior and board and secretary Faa. Colombo, 1674-2-13. Mark, Van Goens senior is missing in the list of signatories but he is mentioned in the heading.
}

A closer look shows that the content of the plaintext letters are identical. The differences are minor. We may assume that the original and copy letters are identical. We can learn from this the following for the encrypting and decrypting process:

- Catchwords as page numbers are used both in the ciphertext and the plaintext.

- Symbol meaning full or whole, see Table 5, is used both in the cipher- and the plaintext.

- Abbreviations are used with the same words in the ciphertext and the plaintext.

- Year 1674 as number in the plaintext appears anno 74 or seventy and four in the ciphertext. Particularly striking is that the place name and date of signing and encrypting are completely converted into words and then encrypted. As a result, a first look at the ciphertext will give the enemy at the end of the letter no indication of the sender or date of shipment.

- In the plaintext of Letter One - in Letter Two we do not find this - there are three places where the text is written bigger and in calligraphy. This is not reflected in the ciphertext. These sentences were more important and certainly have been an important part of Leeuwenson's additional oral information (see Subsection 3.2).

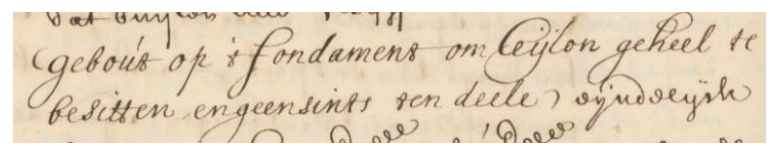

Figure 4: First of three sentences written bigger and in calligraphy in the plaintext (Van Goens, 1674a).

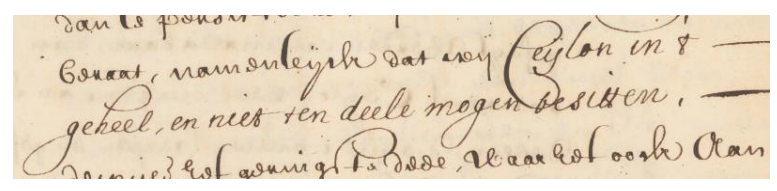

Figure 5: Second sentence written bigger and in calligraphy in the plaintext (Van Goens, 1674a).

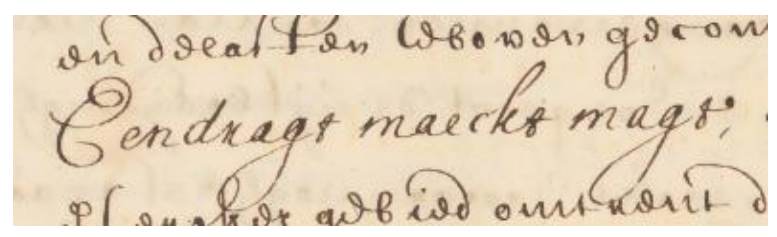

Figure 6: Third sentence that is written bigger and in calligraphy in the plaintext (Van Goens, 1674a). 
Sentences:

1. Dutch: Gebout op 't fondament om Ceijlon geheel te besitten en geensints ten deele. (English: built on the foundation to possess all of Ceylon and not only a part). See Figure 4.

2. Dutch: Ceijlon in 't geheel, en niet ten deele mogen besitten. (English: owning Ceylon in its entirety and not a part). See Figure 5.

3. Dutch: Eendragt maeckt magt. (English: unity is strength). See Figure 6.

\section{How important was sending the ciphertext?}

What Van Goens senior didn't tell in Letter One nor in Letter Two of the ciphertext is that the conquest of the interior of Ceylon didn't go as planned. In fact, he lied when he wrote in Letter Two that he "absolutely" overcome the attacks from the men of the King of Kandy. The King waged a guerilla war since 1670 and Van Goens senior and his soldiers didn't have an adequate answer to that (Arasaratnam, 1956).

\subsection{An echo in 1675 of his 'Vertoog' from 1655}

For Van Goens senior an expansion was the only military-strategic solution to solve the threat of the French and other European competitors in the Ceylon region. Next to that, Arasaratnam (1956) shows that the Ceylon government had, between 1666-1674, serious financial problems. The expenses were significantly higher than its income.

From 1665 onwards, Van Goens senior sent many letters and reports to the governor general in Batavia and the Lords Seventeen in The Netherlands, pleading for his great Ceylon project. To quote Arasaratnam (1956: 80), starting from 1673: "There was a sense of urgency in Van Goens' efforts, for he realised that if his schemes were not adopted then, they would never be put into operation." With the French trapped, in St. Thomé on the Coromandel coast since 1672, he made another bold (Dutch: recklige stoute) move. An echo of his 'Vertoog' from 1655 were he got an approval for his strategic plans after presenting them personally. To enforce his strategic plans from 1674 he sent his secretary Leeuwenson in person to The Netherlands. That was most important for Van Goens senior.

\subsection{Did Van Goens senior get what he asked for?}

Did Van Goens senior get a 'Go!' for his 1674 plans? The answer is: 'No!' The Lords Seventeen changed their expansive strategy in the fall of 1673 - one and a half year before Leeuwenson was able to deliver the letter and even before Van Goens senior wrote it - to a defensive strategy: spend less money as a company by reducing the number of soldiers and addressing the sprawl of fortifications.

Van Goens senior's request to conquer the interior of Ceylon and the island Ramanacoil and the area around it and to obtain 1,000 more soldiers was denied. Ramanacoil was a bridge too far.

\section{Ciphertext and key}

This section shows technical details about the used cipher and the key.

\subsection{Technical analysis}

The cipher is a monoalphabetic substitution cipher where every plaintext letter is always replaced with the same symbol of the ciphertext alphabet. Of the 26 letters of the Latin alphabet 24 are being used. The letters $V$ and $J$ are missing. There are symbols for the following five double letters: $E E, F F, L L, O O$, and $P P$. There are seven words that have a separate nomenclature element (code symbol), for example one is used for Ramanacoil.

Only numbers occur as inline cleartext. Catchwords are used as page numbers. Abbreviations and punctation marks are also used. An abbreviation is not always written in the same way. The way abbreviation marks should be interpreted and expanded depends on their context in the sentence. For example $\stackrel{\hbar}{=}$ is 
OORT in ANTW[OORT] and EIT in SWARIGH[EIT].

\begin{tabular}{|c|c|c|}
\hline $\begin{array}{l}\text { Plaintext } \\
\text { symbol(s) }\end{array}$ & $\begin{array}{l}\text { Number of } \\
\text { ciphertext } \\
\text { symbols }\end{array}$ & Notes \\
\hline Latin letters $A$ to $Z$ & 24 & $\mathrm{~V}$ and $\mathrm{J}$ are missing. \\
\hline Double Latin letters & 5 & $\mathrm{EE}, \mathrm{FF}, \mathrm{LL}, \mathrm{OO}$, and PP \\
\hline Words & 7 & $\begin{array}{l}\text { UEDLE, ENDE, RAMANACOIL, } \\
\text { CEYLON, EYLAND, VDR, and } \\
\text { SOO }\end{array}$ \\
\hline $\begin{array}{l}\text { Total code symbols } \\
\text { according to key }\end{array}$ & 36 & \\
\hline $\begin{array}{l}\text { Code symbols not } \\
\text { in key }\end{array}$ & 1 & $\begin{array}{l}\text { Meaning full or whole. } \\
\text { Example: for } 40 \text { whole guilders }\end{array}$ \\
\hline Abbrevations & 9 & $\begin{array}{l}: 3,=3,=\mathrm{R},=\mathrm{S},=\mathrm{T},=\mathrm{A},=\mathrm{M},=\mathrm{O} \text {, and } \\
=\mathrm{L}\end{array}$ \\
\hline Punctuation marks & 9 & $\begin{array}{l}\text { (colon), --- (line), . (stop), , } \\
\text { (comma), ' (apostrophe), (space), // } \\
\text { (forward slashes), ... (ellipsis), and } \\
\text { (: :) (round brackets) }\end{array}$ \\
\hline Total code symbols & 55 & \\
\hline
\end{tabular}

Table 5: Symbols used in the cipher.

The key consists of 36 graphical signs, as shown in Table 5. (See Figure 1 for a facsimile of the key). Only one symbol in the ciphertext is not accounted for in the key. This is the symbol for full or whole.

\begin{tabular}{|c|c|c|c|c|}
\hline $\begin{array}{l}\text { Key } \\
\text { symbol }\end{array}$ & Key definition & Transcription & Count in cipher & $\begin{array}{l}\text { In plaintext } \\
\text { Van Goens 1674a }\end{array}$ \\
\hline बी & UEDLE & $\langle$ Equivalent $>$ & 187 & 'दिश? \\
\hline \multirow{2}{*}{ C } & \multirow[t]{2}{*}{ EN(DE) } & \multirow[t]{2}{*}{$<$ Sun $>$} & \multirow[t]{2}{*}{829} & en and ende \\
\hline & & & & in inds \\
\hline L & RAMANACOIL & $<\mathrm{L}>$ & 0 & \\
\hline UI & CEYLON & $<$ Cup $>$ & 0 & \\
\hline 1 & EYLAND & $<$ Leaf $>$ & 0 & \\
\hline 7 & VDR & $<$ Corner $>$ & $\begin{array}{l}\quad 1 \\
\text { Probably } \\
\text { Leeuwenson read } \\
\text { number } 7 \text { instead } \\
\text { ofletter } T\end{array}$ & \\
\hline$\Pi$ & SOO & <ntersection> & 0 & \\
\hline
\end{tabular}

Table 6: Counts of occurrences of nomenclature elements within the ciphertext.

Only two of the seven nomenclature elements appear in the ciphertext, UEDLE (English: Your Lordship) and ENDE (English: and), as shown in Table 6. The other nomenclature elements are not used in all of the 39 pages of ciphertext.

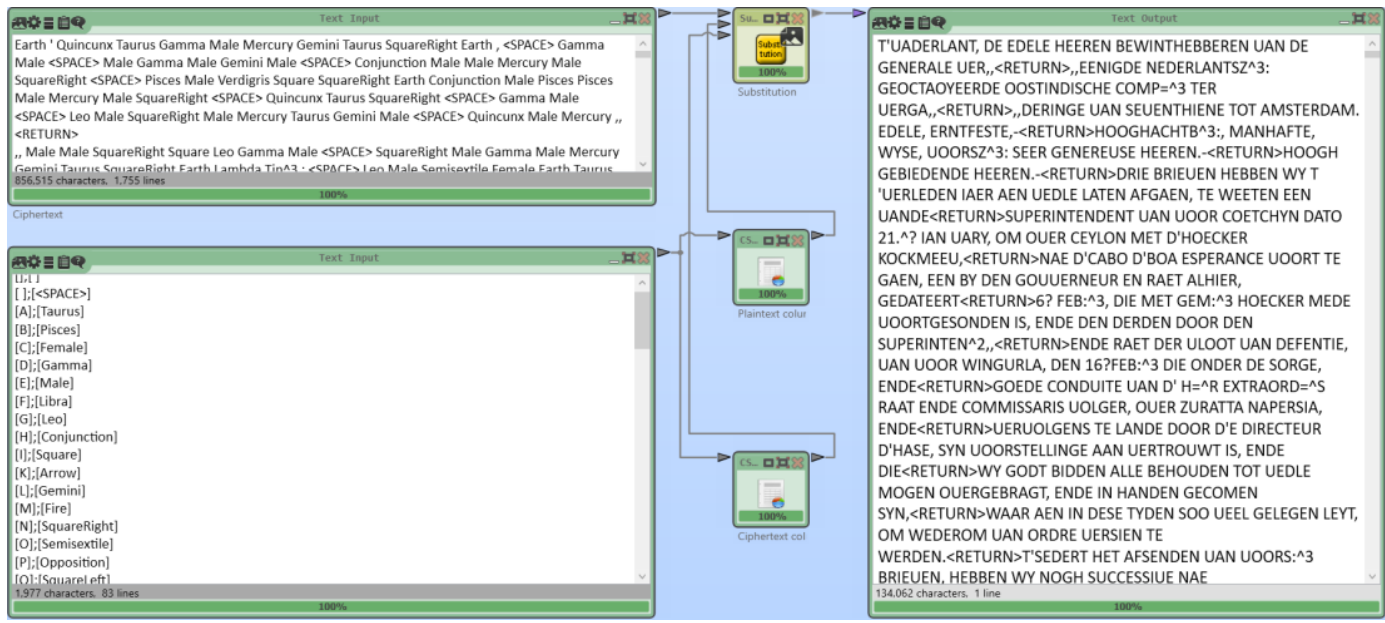

Figure 7: CT2 Substitution component decrypting the ciphertext using the digitized key.

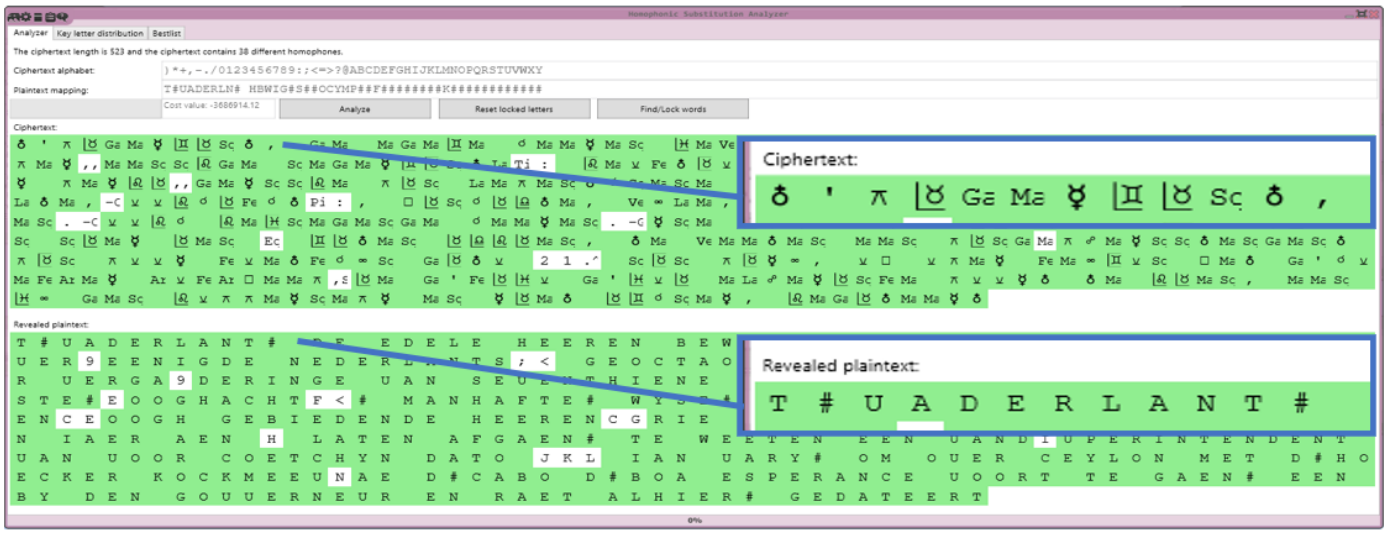

Figure 8: CT2 Homophonic Substitution Analyzer component. The upper rectangular text part of the screenshot shows the transcribed ciphertext. The lower rectangular text part shows the deciphered plaintext. 
The word CEYLON occurs 42 times in Letter One and 23 times in Letter Two of the revealed plaintext as separate alphabetic letters instead of using the corresponding nomenclature element. The word RAMANACOIL occurs respectively three times in Letter One and once in Letter Two, also without using its nomenclature element. This seems to indicate that Leeuwenson did not make the key himself when he had to encrypt the letters in 1674. It makes no sense to add symbols to a key that are not being used in a ciphertext. It also seems to indicate that this is not the key that he wrote down before he arrived in Amsterdam on 1675-1-5. He should still have known very well, after his overland journey, which symbol represents which letter. Encrypting the two letters in 1674 must have taken him a few days of work.

\subsection{Cryptanalysis with CrypTool 2}

We employed our open-source software CT2 to perform automatic as well as semi-automatic cryptanalysis. At first, CT2 can be used to identify the used type of cipher. After the identification, special components for cryptanalyzing and breaking the cipher can be applied. CT2 implements a graphical programming language, which allows combining different ciphers as well as cryptanalysis methods, implemented in components. CT2 contains, for example, special components for cryptanalyzing monoalphabetic, polyalphabetic, and homophonic ciphers. See Kopal (2018) for a more detailed introduction to CT2 and its components. Since we were in possession of the original key, which appears in the document, there was no need to perform a cipher type analysis. From the start, we assumed that the cipher is a monoalphabetic substitution cipher with some nomenclature elements. Therefore, we entered the key manually into CT2. With the help of the substitution component, we were able to decrypt most parts of the ciphertext correctly (see Figure 7). Additionally, we used the Homophonic Substitution Analyzer of CT2, since it allows viewing the plaintext and ciphertext below each other (see Figure 8). In addition, the Homophonic Substitution Analyzer is able to visualize some of the original ciphertext symbols using UTF-8 characters (but this feature is still work in progress).

\subsection{Tips and tricks for digital transcriptions done manually}

As the CT2 software worked easy and flawlessly it can be a meaningful tool for historians, too.

We have four tips and tricks for digital transcriptions that are done manually:

1) Use a tool for counting unique words. The biggest constraint was to get a digital transcription without duplications and errors in the list of used transcription symbols. The symbol is, by the different members of the transcription team, transcribed as Earth. But in the early versions there were also variants that were apparently a typo, for example eArth, Eerth, or earth. CT2 will not recognize the typos and the result is that symbols, that are not represented in the CT2 key, will not be decrypted. We have overcome this by using Unique Words Count ${ }^{4}$ on the digital transcribed ciphertext and then cleaned up the errors before entering it into CT2

2) End every transcribed ciphertext line with a hard return. When the number of pages is large or the lines of the ciphertext are close together, it is useful to have each line in the transcription on a separate line by using a hard return. This will result in separate lines in the revealed plaintext too. This makes it easier to compare the ciphertext with the plaintext, line by line.

3) The DECODE database gives uploaded images of ciphertexts a unique name. This name differs from the original name. To avoid postprocessing or rework in the plaintext, every time after generating a new output, you can add the name of the image in DECODE and original in the nomenclature of $\mathrm{CT} 2$, for example [DC6955_RAM003];[6955]. 6955 is the name of the image in DECODE and RAMOO3 refers to the third scan of the Ramanacoil ciphertext. Having them both automatically makes it easy to navigate between the pages in both sources. One could also add the name of the folio, for example f544r. [DC6955_RAM003_f544r];[6955] is then the corresponding nomenclature.

\footnotetext{
${ }^{4}$ Unique words count at https://planetcalc.com/3205/.
} 
4) The transcription team did identify two symbols in the ciphertext, which in retrospect were differently written variants of existing symbols. If in doubt, one should create a new symbol and don't smuggle them away. In the output one can analyze these new symbols and resolve them in the key of CT2.

\section{Conclusions}

Our main findings have been:

1) The plaintext of the deciphered ciphertext reveals two letters that, in retrospect, were already known in the National Archives as plaintext letters (Van Goens, 1674a and 1674b). We have been able to relate them.

2) The ciphertext and the six additional letters bring to light that for Van Goens senior the letter from 1674-1-24 was of utter importance. His personal secretary Leeuwenson had to encrypt them and deliver the letters in person with additional oral information. This paper shows that Van Goens senior wanted to repeat his most successful 'Vertoog' from 1655. Substantiate his goals and get approval for them from the Lords Seventeen. While in 1655 he got a 'Go!', twenty years later in 1675 he got a 'No!'.

3) The encryption process consisted of using the key but also of additional steps, which are not described, to make cryptanalysis more difficult. For example, the year 1674 in the signature is converted into written words before encryption.

\section{Acknowledgments}

We would like to thank the following persons. Karl de Leeuw for introducing Dinnissen to the DECRYPT team. Guido van Meersbergen for his revealed plaintext and pointing us at Van Goens, 1674a and 1674b. Crina Tudor and her team of students for the digital transcription of the ciphertext. This work has been supported by the Swedish Research Council, grant 2018-06074: DECRYPT-Decryption of historical manuscripts.

A book is planned for the ciphertext with an introduction and annotations as a facsimile of Ramanacoil (1674), the revealed plaintext in Dutch, and with a translation into English. This publication will also include Van Goens, 1674a, 1674b, 1674c, 1674d, and De Hase, 1674.

\section{References}

Sinnappah Arasaratnam. 1958. Dutch Power in Ceylon 1658-1687.

Femme Gaastra. 2012. Geschiedenis van de VOC.

Rijckloff van Goens, 1674a. 1674-1-24. NL-HaNA, VOC, 1.04.02, inv.nr. 1298: ff246-256.

Rijckloff van Goens, 1674b. 1674-1-23. NL-HaNA, VOC, 1.04.02, inv.nr. 1298: ff300-340.

Rijckloff van Goens, 1674c. 1674-1-24. NL-HaNA, VOC, 1.04.02, inv.nr. 1303: unfoiled, scans 191-198.

Rijckloff van Goens, 1674d. 1674-2-10. NL-HaNA, VOC, 1.04.02, inv.nr. 1292: ff539-543.

De Hase, 1674. 1674-5-2. NL-HaNA, VOC, 1.04.02, inv.nr. 1302: ff727-731.

Nils Kopal. 2018. Solving Classical Ciphers with CrypTool 2. Proceedings of the $1^{\text {st }}$ Conference on Historical Cryptology, HistoCrypt 2018: 29-38.

Gerrit Knaap and Ger Teitler editors. 2002. De Verenigde Oost-Indisch Compagnie: Tussen Oorlog en Diplomatie.

Gerrit Knaap, Henk den Heijer and Michiel de Jong. 2015. Oorlogen Overzee: Militair optreden door compagnie en staat buiten Europa 1595-1814: 85$122 ; 430-432$.

Joannes Leeuwenson, 1675. 1675. NL-HaNA, VOC, 1.04.02, inv.nr. 4894: unfoiled, scans 0001-0280.

Leupe. 1863. Daghregister van de landreijs, gedaen bij mij Joannes Leeuwenson... beginnende anno 1674. Bijdragen tot de Taal- Land- en Volkenkunde van Nederlandsch Indië VI: 94-112.

Guido van Meersbergen. 2009. 'In goede en vertroude handen': Communicatie en beleid bij de VOC tijdens de Hollandse Oorlog (1672-1678).

Guido van Meersbergen. 2011. 'In goede en vertroude handen': Communicatie en beleid bij de VOC tijdens de Hollandse Oorlog (1672-1678). De Zeventiende Eeuw, 27 (1): 80-101.

Beáta Megyesi, Nils Blomqvist and Eva Pettersson. 2019. The DECODE Database. Collection of Historical Ciphers and Keys. Proceedings of the $2^{\text {nd }}$ Conference on Historical Cryptology, HistoCrypt 2019: 69-78.

Ramanacoil, 1674. 1674-1-23 and 1674-1-24. NL-HaNA, VOC, 1.04.02, inv.nr. 1292: ff544-563. 